DOI: $10.20472 / S S .2019 .8 .1 .006$

\title{
THE ROLE OF THE STATE ON THE PRIVATE LAW THROUGH NOTARY AS A PUBLIC OFFICIAL IN LEGAL SYSTEM IN INDONESIA
}

\author{
CIPTO SOENARYO, DEWI KANIA SUGIHARTI
}

\begin{abstract}
:
The legal system in Indonesia embraces the division: public law and private law, which is one of the characteristics of the civil law system. The government, as an organ of the state, also assigns some of its duties and authorities to the public official. A public official is a functionary appointed and discharged by the authority of the state, represented by the government, and authorized and obliged to serve the public in certain matters because he or she participates in exercising the authority of the government. Notary, as a general functionary or public official, performs state duty in making authentic deed in order to serve (if requested) society; and the authentic deed made is a state document. In its development, there has been a shift of the notarial position as a public official - who is a part of the state organs - to become no longer a public official but a general profession. This is because if there is a legal issue concerning the authentic deed that is made, it is often contested through the general court rather than through the administrative court of the state. Therefore, the role of the state is necessary in strengthening the legal system.
\end{abstract}

\section{Keywords:}

public law, private law, public official, notary

JEL Classification: K10

\section{Authors:}

CIPTO SOENARYO, Universitas Padjajaran, Indonesia, Email: cipto.dkk@gmail.com DEWI KANIA SUGIHARTI, Universitas Padjajaran, Indonesia, Email: c1pto_5@yahoo.com

\section{Citation:}

CIPTO SOENARYO, DEWI KANIA SUGIHARTI (2019). THE ROLE OF THE STATE ON THE PRIVATE LAW THROUGH NOTARY AS A PUBLIC OFFICIAL IN LEGAL SYSTEM IN INDONESIA. International Journal of Social Sciences, Vol. VIII(1), pp. 68-80., 10.20472/SS.2019.8.1.006 


\section{Introduction}

Indonesia is a country based on law. From and because of that, the existing and applicable legal order in Indonesia is to protect the interests of the Indonesian people. Therefore, since the Indonesian nation declared its independence on August 17, 1945, it has taken the decision to determine and implement its own law, namely the laws of the Indonesian nation as national law with a new legal order, namely Indonesian law. The political attitude of Indonesian law that stipulates the Indonesian legal system is stated in the Preamble of the 1945 Constitution of the Republic of Indonesia, as follows: "Then to form an Indonesian State Government ... the freedom of Indonesian Nationality is drafted in a State Constitution of the Republic of Indonesia".

The attitude of legal politics to enforce the law before the independence day is also included in Article II of the Transitional Rules of the 1945 Constitution (before the Amendment), which states "All existing state entities and regulations are still valid, as long as they have not been established according to this Constitution". Re-enactment of the law (colonial legislation) by the Articles of the Transitional Rules of the 1945 Constitution after the independence on August 17, 1945 cannot say that the Indonesian legal system is a continuation of the Dutch or Japanese colonial legal system. The enactment of colonial legislation was meant to be temporary to avoid a legal vacuum as long as it did not conflict with the soul and spirit of the Proclamation of August 17, 1945 and the 1945 Constitution.

Legal politics is a state policy in the field of law that is being and will be valid in a country. ${ }^{1}$ With the existence of legal politics, the state can determine the types or kinds of law, the form of law, material, and/or sources of law that are applied in a country now and in the future. In addition, it can establish institutions that make or form law (rechtvorming), implementing agencies and law enforcement agencies, investigating institutions or legal interpreters (rechtvinding) in a country. When connected with the notions of "legal politics" and "national", both those that are in force (ius constitutum) and those that will apply (ius contituendum) are meant for the achievement of the goals of the nation and state mandated by the 1945 Constitution.

In the 1945 Constitution, it is stated "Indonesia is a country based on law" with the formula "rechstaat" as mentioned above. The concept of the rule of law in Indonesia is adapted to the condition of Indonesia or is used with a measure of life view on the view of the state by the Indonesian nation. In the symposium at the University of Indonesia in 1966 on "Indonesia is a State of Law", it was emphasized that "the Republic of Indonesia is a state of law based on Pancasila". Pancasila, as the basis of the state that reflects the soul of the Indonesian nation, must inspire all legal regulations and their implementation. In Indonesia, where the philosophy of Pancasila is so pervasive, that the Indonesian state can be called the state of Pancasila, the principle of kinship is the starting point of society. ${ }^{2}$ In the symposium it was stated that: "The nature of a state of law is where the equipments can act in accordance with and bonded with the rules that have been determined in advance by equipment authorized to carry out the rule, or for short, it is called the principle of rule of law". In Article 1 Subsection (3) of the 1945 Constitution

1 SUGIARTO, UMAR SAID (2015). Pengantar Hukum Indonesia, Sinar Grafika, Jakarta, 2015.

2 Fakultas Hukum dan IImu Pengetahuan Kemasyarakatan (FHIPK) (1966). Universitas Indonesia, Simposium Indonesia Negara Hukum, Jakarta 1966. 
Amendment 4, it is stated that: "The State of Indonesia is a state of law". The provision of the article constitutes a constitutional basis that Indonesia is a country based on law; the law is placed as the only rule of play in social life, nation and state (supremacy of law). Thus, the concept of the Indonesian state of law according to the 1945 Constitution is the state of law of Pancasila, namely the concept of a state of law in which one party must meet the criteria of the concept of a rule of law in general. The characteristics for a state of law are:

1. Recognition and protection of human rights, which contain equality in political, legal, social and cultural fields;

2. Courts that are free and impartial and are not influenced by any powers;

3. Legality in the sense of all forms. ${ }^{3}$

Thus, the concept of a legal state that is built is then given a constitutional basis by the 1945 Constitution as a state of law. Indonesia adheres to a system of legal sovereignty or rule of law, where the law has the highest power in the country, and the characteristics of the rule of law can be seen in the practice of government in Indonesia, namely the existence of free and impartial judicial power and recognition of human rights, although in practice the implementation is still not perfect and there are many deviations from the characteristics of the rule of law.

The legal system in Indonesia adheres to the division of public law and private law, which is one of the characteristics of civil law system. The government, as a state organ, also provides part of its duties and authorities to public officials. Public officials are officials who are appointed and dismissed by the power of the state represented by the government and given the authority and obligation to serve the public in certain matters, because they also carry out the authority of the government in law enforcement.

Notary, as a public official, carries out state duties in terms of ascertaining and/or making authentic deed to serve (at the request of) the society and an authentic deed which is ascertained and/or made as a perfect proof of an act and/or legal event, which is subsequently stored by a notary representing the state. In its development, there has been a shift in the position of a notary as a Public Official who is part of a state organ that is no longer a public official, but as a profession, because if there is a legal problem (dispute) against an authentic deed that he/she ascertains and/or makes, it is often filed to the general court not to the state administrative court.

Considering that law covers almost all aspects of national and state life, it is very important to improve the development of the law in line with the development of society so that the legal aspirations to be achieved by the existence of a legal state can be achieved and the results can be felt equally by all levels of society and evenly without exception.

\section{Public Officials Authorized to Make Authentic Deeds}

The Indonesian legal system adheres to an open legal system, in which the open system has a reciprocal relationship with its environment. This open legal system is a unity of elements (i.e. regulations and stipulations) which are influenced by cultural, social, economic, historical and

3 SUHARDIN, YOHANES; SIAHAAN, RUDY HAPOSAN (2014). Pengaruh Budaya Sistem Hukum Asing Terhadap Negara Hukum Kesejahteraan Indonesia. 
other factors. And conversely, the legal system influences factors outside the legal system. The legal regulations are open to different interpretations, therefore there is always development. ${ }^{4}$

The Indonesian legal system that has a special characteristic is strongly influenced by the form of the legal system that surrounds it, especially the world's legal system that is now in effect throughout the world. The Indonesian legal system that is in force today is strongly influenced by the Continental European legal system, as seen from the history of Indonesia, having applied the laws of the Netherlands based on the concordance principle during colonialism and then until now there are still those laws that are still in force, as affirmed in Article II of the Transitional Rules of the 1945 Constitution (prior to the Amendment), which states: "All existing state entities and regulations are still directly applicable, as long as a new constitution has not been established, according to this constitution". In addition to these two systems, what has become characteristic of the Indonesian legal system is the customary law system and the Islamic legal system. The two latter systems are elements of the Indonesian legal system as a distinctive feature inherent in the sources of law in Indonesia. Customary law systems exist and develop in the environment of social life in Indonesian society, while the Islamic legal system originated in Arabia, then developed in Indonesia in line with the entry of Islam into Indonesia, so that Islamic law is one of the sources of national law in Indonesia.

Based on the following classification of legal fields, since long time ago the legal system (positive law) has been known in European countries using continental legal system (civil law system) including in the Netherlands and its colonies (Dutch East Indies / Indonesia):

1) Field of public law, including: criminal law (material) or (ius poenale / strafrecht / criminal law); constitutional law (material) or (staatsrecht / vervassungsrecht) or droit constitutionel); state administrative law (material) or administratief recht / verwaltungsrecht or droit administrative); international law (internationaal recht / international public recht or droit international; criminal procedural law (formal criminal law / straf process recht); constitutional procedural law (formal state administrative law / administratief proces recht); formal constitutional law / proces constitusional law / constitutional proces recht.

2) Field of private law, including: civil law (privaatrecht / burgerlijk recht); commercial law (handelsrecht); international private law (international privaatrecht); civil procedural law (formal civil law / burgerlijk process rechts).

The term civil law (privaat recht) is used as the opposite of the term public law (publiekrecht). What is meant by civil law is a set of legal rules governing acts or relationships between humans or civil legal entities for the benefit of the parties themselves from other parties concerned with them, without involving a wider public interest. Therefore, civil law is not classified into public law, where public law is more concerned with the public interest.

The Civil Code is the main source of civil law in Indonesia. This Civil Code is a product of the Dutch civil law (Burgerlijk WetBoek) which is applied by the principle of concordance, which means that the law that applies in the country of the colonizer (Netherlands) is the same as in the colonized country. Then, after the independence day, the civil law in Indonesia was based on

4 MERTOKUSUMO, SUDIKNO (2015). Mengenal Hukum Suatu Pengantar, Liberty, Yogyakarta, 2015. 
Article II of the Transitional Rules of the 1945 Constitution (before the Amendment), which basically stipulates that all regulations are declared valid before new regulations are made according to the 1945 Constitution, including the Dutch civil law (Burgerlijk WetBoek) that applies in Indonesia. This is to prevent a legal vacuum (rechtvacuum) in the field of civil law. Besides, although the Dutch Civil Code is still valid in Indonesia, Indonesian civil law in its history has completely undergone several processes of change in which the changes are adapted to the condition of the Indonesian personality and the Pancasila which contains 1) Belief in One Almighty God; 2) Fair and Civilized Humanity; 3) Unity of Indonesia; 4) Populism Lead by Wisdom in the Consultation of Representatives; 5) Social Justice for All Indonesian People.

The Civil Code, as a legal subsystem in Indonesia, consists of four sections, namely: 1) Book on People (Van Personnenrecht); 2) Book on Objects (Van Zaken); 3) Book on Contract (Van Verbintenessenrecht) and 4) Book on Proof and Expiry (Van Bewijs en Verjaring). Regarding Book on Proof and Expiry (Van Bewijs en Verjaring), Article 1868 states that an authentic deed is a deed which is in the form specified by the law, made by / in the presence of a public official who is in charge of it at the place where the deed is made. This shows that there is a public official who is authorized by a general authority to make an authentic deed which is a perfect proof. Therefore, a Public Official is a position that is carried or given to those who are authorized by the rule of law in making authentic deeds.

Table 1: Public Officials Given Authority to Make Authentic Deeds

\begin{tabular}{|c|c|c|c|}
\hline No & Position & Authority & Regulation \\
\hline 1. & Notary & $\begin{array}{l}\text { Authentic deeds regarding any actions, } \\
\text { agreements and provisions required by laws } \\
\text { and/or as desired by the interested parties } \\
\text { to be stated. }\end{array}$ & $\begin{array}{l}\text { Law No. 30/2004 connected } \\
\text { with Law No. } 2 / 2014\end{array}$ \\
\hline 2. & $\begin{array}{l}\text { Land Titles } \\
\text { Registrar }\end{array}$ & $\begin{array}{l}\text { Deeds related to land: Sale and Purchase } \\
\text { deed; Grant Documents; Exchange Deed; } \\
\text { Deed of entry into the company; Joint Rights } \\
\text { Distribution Act; Underwriting Right; } \\
\text { Granting of Right to Use Building / Right to } \\
\text { Use on Freehold Land; Deed of Power of } \\
\text { Attorney Charging Underwriting Rights. }\end{array}$ & $\begin{array}{l}\text { Government Regulation No. } \\
24 / 1997 \text { connected with } \\
\text { Government Regulation No. } \\
37 / 1998 \text {, connected with } \\
\text { Government Regulation No. } \\
24 / 2016\end{array}$ \\
\hline 3. & $\begin{array}{l}\text { Ship Deed } \\
\text { Officer }\end{array}$ & $\begin{array}{l}\text { Deed of Sale and Purchase and Lien of } \\
\text { Ship }\end{array}$ & $\begin{array}{l}\text { Regulation of Minister of } \\
\text { Transportation No. 39/2017 }\end{array}$ \\
\hline 4. & $\begin{array}{l}\text { Civil } \\
\text { Registration } \\
\text { Officer }\end{array}$ & $\begin{array}{l}\text { Birth Certificate; Death Certificate; Marriage } \\
\text { Certificate; Divorce Certificate. }\end{array}$ & Law No. $24 / 2013$ \\
\hline 5. & $\begin{array}{l}\text { Auction } \\
\text { Officer }\end{array}$ & Treatise of Auction & $\begin{array}{l}\text { Law of Auction (Vendu } \\
\text { Reglement) Staatsblad } \\
\text { 1908: } 189 \text { amended to } \\
\text { Staatsblaad 1941: } 3 \text { dan } \\
\text { Regulation of }\end{array}$ \\
\hline
\end{tabular}




\begin{tabular}{|l|l|l|l|}
\hline & & $\begin{array}{l}\text { Minister of Finance No. } \\
93 / \text { PMK.06/2010 }\end{array}$ \\
\hline
\end{tabular}

Source: Indonesia's legislations

Subsequently, authentic deeds that are ascertained and/or made by the public officials are said to be perfect proof because they have the following physical, formal and material evidentiary powers:

1. The power of physical proof: the deed itself has the power to prove itself as an authentic deed because of its presence and birth are in accordance with / determined by the laws governing it;

2. The power of formal proof: what is stated in the deed is true;

3. The power of material proof: the deed provides certainty of what events described in the deed are true.

The authority of the public officials mentioned above in ascertaining and/or making authentic deeds is the authority given by a general power (legislations) to represent the state, in accordance with the purpose of the state to carry out legal traffic order in order to achieve a just and prosperous society. The purpose of the state to maintain and guarantee legal order in the society and country is to maintain and guarantee human rights, namely: 1) rights to life (leven); 2) rights to bodies (lijf); 3 ) rights to properties (vermogen); 4) rights to honor (eer); and rights to independence (vrij heid).

The state is a public legal institution that has general power and a governmental organ in which state administrative officials perform governmental affairs. This means that there is a position based on an authority delegated. On that basis, the position is given authority by regulations and in the position is contained authority to carry out government actions. The position holders referred to as officials are individuals who occupy that position to run real or concrete benefits for the state. ${ }^{5}$

Authority is an implication of legal relations. ${ }^{6}$ Authority, which is defined as the right and power to act, is the power to make decisions, govern and delegate responsibilities to other people/bodies. So, authority is the ability to act based on legitimate power. It is described as the ability to act because the phrase "to act" means to do action, to be in action, to behave, conducts, actions, and steps that indicate an ability. That ability must be based on legitimate power. The laws are the matters that legitimize the power, in order to be legitimate. Authority is born because of lawful power. An action of a public official is said to be illegal (arbitrary) if it is not based on law. It is important to understand that power and authority are interrelated but do not have the same meaning.

In the concept of public law, authority relates to power. As a concept of public law, authority consists of at least three components, namely influence, legal basis, and legal conformity. The influence component refers to the use of authority intended to control the behavior of legal

5 BASAH, SJACHRAN (1997). Eksistensi dan Tolak Ukur Badan Administrasi Negara di Indonesia, Alumni, Bandung 1997.

6 SUDRAJAT, TEDI (2017). Hukum Birokrasi Pemerintah, Kewenangan \& Jabatan, Sinar Drafika, Jakarta, 2017. 
subjects. The legal basis component refers to an understanding that an authority must always have legal basis, and legal conformity component means that there is a standard of authority, namely general standards (for all types of authority) and special standards (for certain types of authority) .

Furthermore, if it is seen from the theory of authority in the state, the giving of authority by the state to public officials falls under attribution authority, which is the giving of authority to state administrative officials based on a formal law. ${ }^{8}$

In an attributive state and government, there is a new government authority by a provision in the laws. An attribution of authority, according to laws, is the giving of authority to form laws, which is at the top is given by the 1945 Constitution to a state institution. This authority is attached continuously and can be carried out on its own initiative whenever needed. Here, a new authority is born or created. The competent legislator to provide attribution of government authority is known as original legislator; in this case, at the central level are the People's Consultative Assembly as former of the Basic Constitution and the House of People's Representatives together with the government as formers of laws. In relation to regional affairs, Regional House of People's Representatives is involved. At the regional level, Regional Regulations are produced by Regional House of People's Representatives and Regional Government. For example, the 1945 Constitution after the amendment in Article 5 Subsection (2) gives authority to the President in stipulating Government Regulations to carry out laws as it should. Article 22 Subsection (1) of 1945 Constitution authorizes the President to form a Government Regulation in Lieu of Law if there is a compelling interest.

Government agencies and/or officials obtain authority through attribution if: ${ }^{9}$

a. Regulated in the 1945 Constitution of the Republic of Indonesia and/or the laws;

b. They are new authorities or previously absent;

c. The attribution is given to the Government Agencies and/or officials.

Government agencies and/or officials that obtain authority through attribution bear resposibilities. Attribution authority cannot be delegated, except as provided for in 1945 Constitution of the Republic of Indonesia and/or the laws. Government agencies and/or officials obtain authority through delegation if: given by government agencies and/or officials to other government agencies and/or officials; stipulated in Government Regulations, Presidential Regulations, and/or Regional Regulations; and are devolved by previously existing authorities.

C.F. Strong interprets a government in a broad sense as a complete state organization with all state apparatus that has legislative, executive and judicial functions. In other words, a state with all its apparatuses is a definition of government in a broad sense, whereas the definition of government in a narrow sense only refers to one function, namely the executive function. ${ }^{10}$ Based

7 HARJON, PHILIPUS M. (2013). Wewenang Pembatalan Peraturan Daerah, Journal Law Review, Vol. XII No. 3 Tahun 2013.

8 KOENTJORO, DIANA HALIM (2004). Hukum Administrasi Negara, Ghalia Indonesia, Jakarta, 2004. 9 MUSKAMAL (2016). Jurnal Administrasi Publik Volume XII Nomor 2 Desember 2016.

10 STRONG, C.F. (1963). Modern Political Constitution, Sidgwick and Jackson, London, 1963. 
on Strong's opinion, the definition of state officials will refer to the definition of government in a broad sense, whereas the definition of government officials will refer to the definition of government in a narrow sense, or officials who are in the government environment alone - in the executive branch.

Besides state officials, there are also public officials. Openbare Amtbtenaren, which is translated as a public official, is defined as an official who is entrusted with the task of making authentic deeds that serve public interest, and such qualifications are given to notaries and other public officials. From the state administrative law's point of view, these publilc officials are classified as supporting state institutions or supporting entities that function to support the functions of state apparatus. This can be seen from the following categories of state institutions based on their functions: ${ }^{11}$

1. State institutions that carry out state functions directly or act for and on behalf of the state, such as Presidential Institute, House of Representatives, and Institute of Judicial Authority. Institutions that carry out this function are called state apparatus.

2. State institutions that carry out state administrative functions and do not act for and on behalf of the state. This means that these institutions only carry out administrative tasks that are not constitutional. Institutions that carry out this function are called administrative institutions.

3. Supporting state institutions or supporting entities that function to support the functions of state apparatus. These institutions are called auxiliary organ/agency.

Based on such categories, it can be concluded that public officials are in the category of State Institutions that carry out state administrative functions and do not act for and on behalf of the state. This means that this type of institution only carries out administrative tasks that are not constitutional. Institutions that carry out this function are, once again, called administrative institutions, when the authority granted by the state to public officials is based on the authority of Attribution. Law No. 30 of 2014 on Government Administration explains that Attribution is the granting of authority to government entities and/or officials by 1945 Constitution or laws. Therefore, the authority of attribution is the authority inherent in the position or function.

\section{Position of Notary as a Public Official Performing a Part of State Power}

Why is a notary named a Public Official? It is because a Notary is appointed and dismissed by the state (represented by the government through the Minister whose fields of duties and responsibilities include the notary sector, namely the Minister of Law and Human Rights). A Notary carries out state duties; deeds which are ascertained and/or made are a perfect proof of a legal action and/or event which is subsequently stored by the Notary representing the state. The main duty of a Notary is to ascertain and/or make authentic deeds to serve (by request) society. The definition of a Public Official is as follows: Official who is appointed and dismissed by public authority (which is the state represented by the government), and is given the authority and obligation to serve the public in certain matters, therefore, he carries out the authority of the government. This is what distinguishes a Notary from other Officials - such as Advocates, General Doctors, Public Accountants - in society, because even though other Officials are also

11 MANAN, BAGIR (2004). Teori dan Politik Konstitusi, FH-UII Press, Yogyakarta, 2004. 
appointed by the government or get permission from the government, the nature of their appointment is merely the granting of a permission or license to carry out a position, not directly a position of a state official. Those other Officials carry out common jobs, not having the nature of a Public Official, because the work they do does not stem from public power. They are private people who are only bound to regulations regarding the positions or jobs allowing them to independently do their professions. They themselves may choose where they will work, not being bound to leave rules and strict administrative regulations.

According to the history of the birth of the position or office of a notary, in ancient Roman law books and writings are repeatedly found the position or office of the notary. In the book 'Brooke's Notary', the same thing is also stated: "The office of public notary is a public office. It has a long and distinguished history. The office has its origins in the civil institutions of ancient Rome. Public offcials, called scribae, that is to say, scribes, rose in rank from being a mere copiers and transcribers to a learned proffesion of prominent and public affairs". ${ }^{12}$ The profession of scribae in ancient Roman times was an educated person whose job was to record notes and minutes of an activity or decision then make a copy of the either public or private document. The profession of scribae was needed at that time because most people were illiterate.

The word "notary" comes from the word nota literaria which is a character of writing that is used to write or describe an expression of sentences delivered by a speaker. The word "notary" was also used specifically for royal writers who wrote down everything that an emperor talked about at state meetings. Such notary had a position as a royal official, so that it is not in accordance with the notary of today. Some notaries are under the power of the Papacy, known as tabellio and clericus notarius publicus who provide assistance in civil law matters. Emperor Justianus I, in the Roman era, also appointed jurists to help form a type of law regarding the making of deeds. Deeds and letters made by the tabellio did not have authentic power so that the deeds and letters only had the power like an under-hand deed. ${ }^{13}$ Thus, at the beginning of the birth of an office of notary, there were two groups of notaries, namely notaries who were appointed by the kingdom and were royal employees; and private notaries who were not appointed by the kingdom and were not royal employees. Notaries appointed by the kingdom had the right to issue an authentic deed, while notaries not appointed by the kingdom only had the right to issue an under-hand deed. Then, in its development, the position of a notary acts as a public official (public notary) assigned to the public authority to serve the needs of the society of an authentic evidence that provides certainty in the civil law matters. Therefore, as long as authentic evidence is still needed by the state legal system, the position of a notary will still be needed in the society.

In Indonesia, the notary position is regulated in Law of Notary Office No. 30 of 2004 on Notary Office and Law No. 2 of 2014 on Amendment to Law No. 30 of 2004 on Notary Office. In Article 1 Point (1) of both laws, it is stated that a notary is "a public official who is authorized to make authentic deeds and has other competences as referred to in this Law or based on other laws". Furthermore, in Article 15 Subsection (2), it is stated that the other competences are as follows:

12 Brooke's Notary, Chapter 1, Jati Diri Notaris Indonesia. Dahulu, Sekarang, dan di Masa Datang. Pengurus Pusat Ikatan Notaris Indonesia, Jakarta, Gramedia, 2008.

13 LOEMBANTOBING, G.H.S. (1996). Peraturan Jabatan Notaris, Erlangga, Jakarta, 1996. 
a. To validate signatures and determine certainty of date of under-hand letters by registering them in a special book;

b. To make under-hand letters into a book by registering it in a special book;

c. To make copies of the original under-hand letters containing the description as written and described in the letters concerned;

d. To validate the suitability of the copies with the original letters;

e. To providing legal counsel in connection with making deeds;

f. To make land-related deeds;

g. To make deeds of auction documents.

As for other competencies or authorities stipulated in the laws and regulations include notaries as land deed officials, notaries as officials making auction deeds, and notaries as officials making capital market deeds. Regarding the last, the authority is regulated in a separate law.

In connection with notaries' authorities, it is further stipulated in Article 2 of Law of Notary Office stating that a notary is appointed and dismissed by the Minister of Law and Human Rights. In Article 8 , it is stated that a notary is respectfully discharged from his/her position after he/she reaches 65 years of age.

The concept of state organs, in terms of their functions, is divided into two parts, namely normcreating and norm-applying. Hans Kelsen explained: "Whoever fulfills a function determined by the legal order is an organ". The state's organs are not always in an organic form. In addition to organs that are in the organic form, every position determined by law can be called an organ, provided that its functions have the characteristic of norm-creating and/or norm-applying. "These functions, be they of a norm-creating or of a norm-applying character, are all ultimately aimed at the execution of a legal sanction". ${ }^{14}$

Judging from the theory of state authority, which the granting of authority to state administrative officials is based on a formal law or what is called attribution, an authority can be categorized as the granting of authority through attribution. The position of notary, created by the state as an implementation of the state providing services to the people, is a special position, which is noble, honorable and dignified because it is specifically regulated by a separate law regarding the position. Thus, a notary is an official who has his own specialization, because a notary is a state official who carries out duties to provide services to the general public in the field of civil law. The term 'public official' is a translation of the term openbare Amtbtenaren, contained in the provision of Article 1868 of the Civil Code. It is a must to make a notary as a public official, as related to the definition of an authentic deed given by Article 1868 which reads: "An authentic deed is a deed which is in the form determined by law, made by or in the presence of public employees in power for it in the place where the deed is made". Openbare Amtbtenaren, which is translated as public official, serves as an official given a task to make authentic deeds for the public; such qualification is given to notaries. Therefore, based on the provisions of Article 1868 of the Civil Code, to be able to make an authentic deed one must have a position as a public official.

14 KELSEN, HANS (1973). General Theory of Law and State, New York, Russel and Russel, 1973. 
Furthermore, the article clearly specifies that the main task of a notary is to ascertain and/or make authentic deeds which, according to Article 1870 of the Civil Code, serve as a perfect proof. This means that what is in the authentic deed is essentially considered true. This is very important for anyone who needs a verification tool for a need, for both personal and business purposes. The position of a notary as a functionary in society is considered as an official from whom someone can obtain reliable advice about making perfect proof in legal transactions, so that the society has a figure whose provisions are reliable and trustworthy, whose signature (or stamp) provides strong guarantees and proof, and who is an impartial expert and advisor who has no disability and keeps a secret and ascertains an agreement that can protect the society in the future.

Based on the explanation above, a notary is an official who is given authority by the state to carry out some of the state's authorities, namely to ascertain and/or make authentic deeds; and because a notary operates on the basis of power granted to him, the notary is said to be a public official or public notary, with authorities with exceptions. By categorizing Notaries as Public Officials. In this case, the public means law, not the public as a public audience. Notary as a public official does not mean the same as a public official in the government sector which is categorized as a state administrative agency or official; this can be distinguished from the product of each public official. Notary as a public official has an end product in the form of an authentic deed which is bound by provisions of civil law, especially the law of proof. Since a deed is a formulation of wishes or will (wilsvorming) of parties as ascertained and/or made in the notary deed tailored before or by a notary, a dispute in the civil field is still examined in a public court, without including the notary as a party in the the dispute because the deed made by a notary has become a perfect proof acting as an authentic deed. A notary, in conducting his obligation in ascertaining and/or making an authentic deed requested by the society, must do it sincerely, honestly, thoroughly, independently and impartially in accordance with the oath/commitment of the notary. And for that reason, a notary before running his position is obliged to make an oath/vow according to his/her religion in front of the Minister or the appointed official. If there are problems or disputes of law relating to the position of a notary, it can be resolved in a Notary Honorary Council trial, not in a state administrative court. A notary, as a public official or public notary, does have specialization compared to other public officials, because the notary in making the deed is to exercise some of the state's authorities, so that a notary is not a part of public law, but is a part of private law.

In connection with the foregoing, by referring to an opinion put forth by Crince Le Roy, if the branches and twigs are arranged in such a way in the tree of law, we will know the legal structure in the sense of one legal system that is drawn in a chart shaped like a trapezium. In this matter, Crince Le Roy places the constitutional law at the top. ${ }^{15}$ Therefore, the civil and criminal law as well as state administrative law (which deals with all human affairs, from birth to death and where state apparatuses deal with people's affairs) are located under the constitutional or state law. In connection with the goal of the state towards a welfare state, the government's involvement in societal and state-related life increases deeply and far, so as if constitutional law undermined civil law, or, in other words: the interference of public law in private law.

15 MARTOSOEWIGNYO, SRI SOEMATRI (1992). Bunga Rampai Hukum Tata Negara Indonesia, Alumni, Bandung, 1992. 
In this matter's development, we can also see a shift in the position of notary as a public official who is a part of the state organs. This can be known from how the government inconsistently designates the position of a notary as either a public official or a profession. This can also be seen in the legislations governing notaries and several court decisions, which designate a notary as a common profession.

A notary as a public official or public notary is different from other public officials, because a notary has his own specialization; he is appointed and dismissed by the state in his authority to exercise some of the state powers granted to him in making authentic deeds needed by the public as a means of proof. Therefore, notaries who perform their positions must always remember their oath and pay attention to the applicable legal regulations and maintain their dignity by complying with the notary's code of ethics. For this reason, it is necessary to strengthen the legal system, where the notary as a public official or public notary is a sub-system of the legal system in Indonesia in the state system of state institutions, where also the notary receives authority through attribution and is a supporting state institution that functions to support the state's complete function. This is in line with what is said by Crince Le Roy, that there is another power besides the executive, legislative and judicial powers (according to Montesquieu) and that power arises with regard to reality in a state's society.

\section{Conclusion}

1. Notary is a public official or public notary who conducts some of the state's authorities through attribution authority, in ascertaining and/or making authentic deeds requested by the society to him, and the notary must carry out his position with trust, honesty, thoroughness, independence and impartiality, based on his vow/oath as well as legislations and notary code of ethics.

2. In the context of the goal of a state towards a welfare state, there is a participation of government in the life of society and state with the basis of the state of law, giving chance for public law to interfere in private law through state apparatuses/officials authorized by the law to deal with people's affairs.

\section{Reference}

BASAH, SJACHRAN (1997). Eksistensi dan Tolak Ukur Badan Administrasi Negara di Indonesia, Alumni, Bandung 1997.

Brooke's Notary, Chapter 1, Jati Diri Notaris Indonesia. Dahulu, Sekarang, dan di Masa Datang. Pengurus Pusat Ikatan Notaris Indonesia, Jakarta, Gramedia, 2008.

Fakultas Hukum dan Ilmu Pengetahuan Kemasyarakatan (FHIPK) (1966). Universitas Indonesia, Simposium Indonesia Negara Hukum, Jakarta 1966.

HARJON, PHILIPUS M. (2013). Wewenang Pembatalan Peraturan Daerah, Journal Law Review, Vol. XII No. 3 Tahun 2013.

KELSEN, HANS (1973). General Theory of Law and State, New York, Russel and Russel, 1973.

KOENTJORO, DIANA HALIM (2004). Hukum Administrasi Negara, Ghalia Indonesia, Jakarta, 2004.

LOEMBANTOBING, G.H.S. (1996). Peraturan Jabatan Notaris, Erlangga, Jakarta, 1996. 
MANAN, BAGIR (2004). Teori dan Politik Konstitusi, FH-UII Press, Yogyakarta, 2004.

MARTOSOEWIGNYO, SRI SOEMATRI (1992). Bunga Rampai Hukum Tata Negara Indonesia, Alumni, Bandung, 1992.

MERTOKUSUMO, SUDIKNO (2015). Mengenal Hukum Suatu Pengantar, Liberty, Yogyakarta, 2015.

MUSKAMAL (2016). Jurnal Administrasi Publik Volume XII Nomor 2 Desember 2016.

STRONG, C.F. (1963). Modern Political Constitution, Sidgwick and Jackson, London, 1963.

SUDRAJAT, TEDI (2017). Hukum Birokrasi Pemerintah, Kewenangan \& Jabatan, Sinar Drafika, Jakarta, 2017.

SUGIARTO, UMAR SAID (2015). Pengantar Hukum Indonesia, Sinar Grafika, Jakarta, 2015.

SUHARDIN, YOHANES; SIAHAAN, RUDY HAPOSAN (2014). Pengaruh Budaya Sistem Hukum Asing Terhadap Negara Hukum Kesejahteraan Indonesia. 